\author{
Monika Podwórna \\ dr inż. \\ Politechnika Wrocławska \\ Katedra Mechaniki Budowli i Inżynierii Miejskiej \\ monika.podworna@pwr.edu.pl
}

DOI: 10.35117/A_ENG_17_09_02

\title{
Numerical analysis of beam rail bridges - impact factors in the vertical deflection
}

\begin{abstract}
The impact factors in the vertical deflection obtained in dynamic analysis of BTT systems - bridged / track structure / high speed train (BTT) - are discussed. The BTT system is one of 5 bridges spanning from $15 \mathrm{~m}$ to $27 \mathrm{~m}$, modelled as simply supported beams loaded by ICE-3 trains traveling at high speeds. The two-dimensional, physically non-linear BTT model includes: viscoelastic suspension of rail vehicles on two independent axle bogies and non-linear one-sided wheel-rail contact springs according to Hertz theory, access zones for composite construction. The BTT system was divided into subsystems loaded with vertical interactions transmitted by elastic or viscoelastic and physically linear or nonlinear constraints. Using Lagrange equations and internal aggregation of subsystems, discretised according to the finite element method, matrix equations of motion of the subsystems were obtained, with explicit linear left sides and nonlinear implicit right sides, which were integrated numerically using the Newmark method with parameters $\beta_{\mathrm{N}}=1 / 4$, $\gamma_{\mathrm{N}}=1 / 2$. The analysis focus on the effect of random track irregularities on the dynamic response of BTT systems.
\end{abstract}

Keywords: Random vertical track irregularities; Composite steel-concrete railway bridge; Highspeed train

\section{The Oppening}

In Poland Composite Steel-Concrete Railway Bridge are projected according to norms [13-16] or [6-7] and with legal acts [23-24], specyfications mentioned by prof. K. Towpik [26]. Bridges on the high-speed railway lines (KDP) must be projected (new ones), or modernized (actual ones) for ensuring the safety of train movement and convinient of passengers. Carried out literature researches confirmed that one of the main factor affecting on dynamic reply of railway engineering constructions is irregularity in track structure - track irregularity [8, 27, 29], also uneven stiffness of ballast can affect on research results $[1,4,5]$.

\section{Modelling of the BTT system}

BTT system - bridge / track structure / high-speed train consists of freely supported span of the Composite Steel-Concrete Railway Bridge, transition boards, contactless track customized to the high operating speed and the high-speed passenger track. The flat geometrical linear model and physical non-linear, consisting of the subsystems separately modelled was assumed. It is considering to finish the long deformed contactless track, which involve (beyond transitional?) areas, transitional areas and bridge area. The track beyond these areas is non-deformable and rectilinear.

Series of SCB bridges (Symmetric Composite Bridge), described in detail in piece of work [21], was developed by team M.Podwórna and prof. M. Klasztorny, then verified by prof. Cz. Machelski. Series, counting design hints included in a piece of work of Karlikowski, Madaj, Wołowicki [10], consist of 5 objects (SCB-15, SCB-18, SCB-21, SCB-24, SCB-27) with codes informing us about the theoritical breadth of the span. Every bridge has fully symetrical transverse intersection, monorail span, freely supported with rectilinear horizontal axis of the unloaded track. The train model is reflection of german High-Speed Train of the third generation ICE-3 (Inter City 
Express) with maximum operational speed $300 \mathrm{~km} / \mathrm{h}$. The train is built by Siemens Company, and consists of 8 vehicles. Railway vehicle has been modeled as flat expanded model of Matsuura having two biaxal trolleys with lineraly viscoelastic suspensions of first and second levels. To the modelling mass of the wheel sets, the vertical one-sided springs with contact stiffness of Hertz was secured - look at Lei, Nod [11]. The individual vehicle is discreet system with 10 levels of freeness - look at Podwórna, Klasztorny [22].

It is adopted that vertical vibration surface of BTT system overlaps with longitudinal simetrical surface of the system. Physical model of the system bridge / track is symetrical according to the breadth centre of a bridge construction, except inequality of a track which are random - look at picture 1. Vertical inequalities of a track are described by spatial function, which is stationary ergodic Gauss process described by power spectral density function (PSD - Power Spectral Density) - look at [22]: , wherein [rad/m] is spatial frequency, while is length of the wave.

Function developed by Federal Raildroad Administration (FRA) has a form:

$$
\mathrm{S}_{\mathrm{rr}}(\Omega)=\mathrm{kA} \frac{\Omega_{\mathrm{c}}^{2}}{\left(\Omega^{2}+\Omega_{\mathrm{c}}^{2}\right) \Omega^{2}} \quad\left[\frac{\mathrm{mm}^{2} \mathrm{~m}}{\operatorname{rad}}\right]
$$

when the constant, and the factor $\mathrm{A}[\mathrm{mm} 2 \mathrm{rad} / \mathrm{m}]$ is a parameter of vertical inequality of the track, according to $1-6$ railway lines. In this piece of work only the better lines about the levels are incorporated: $4(\mathrm{~A}=53.76), 5(\mathrm{~A}=20.95)$. Random attempts of vertical inequality profiles of the track was generated with help of Monte-Carlo mothod, receiving formulas [11, 28] $\mathrm{r}(\mathrm{x})=2 \sum_{\mathrm{i}=1}^{\mathrm{N}_{\mathrm{r}}} \sqrt{\mathrm{S}_{\mathrm{rr}}\left(\Omega_{\mathrm{i}}\right) \Delta \Omega} \cos \left(\Omega_{\mathrm{i}} \mathrm{x}+\varphi_{\mathrm{i}}\right) \quad[\mathrm{mm}]$.

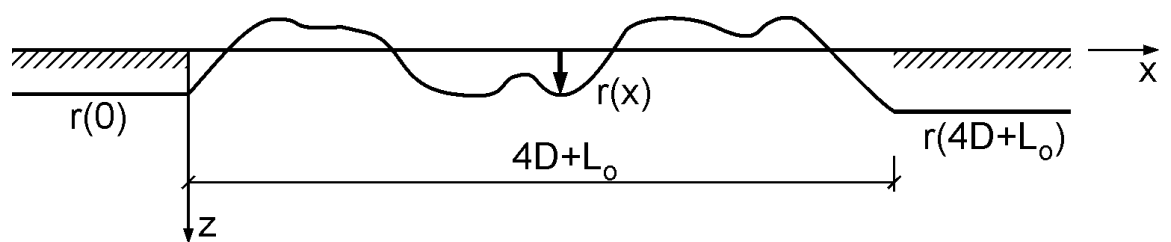

1. Random vertical unevenness of the track in the zone $4 D+L_{o}[22]$

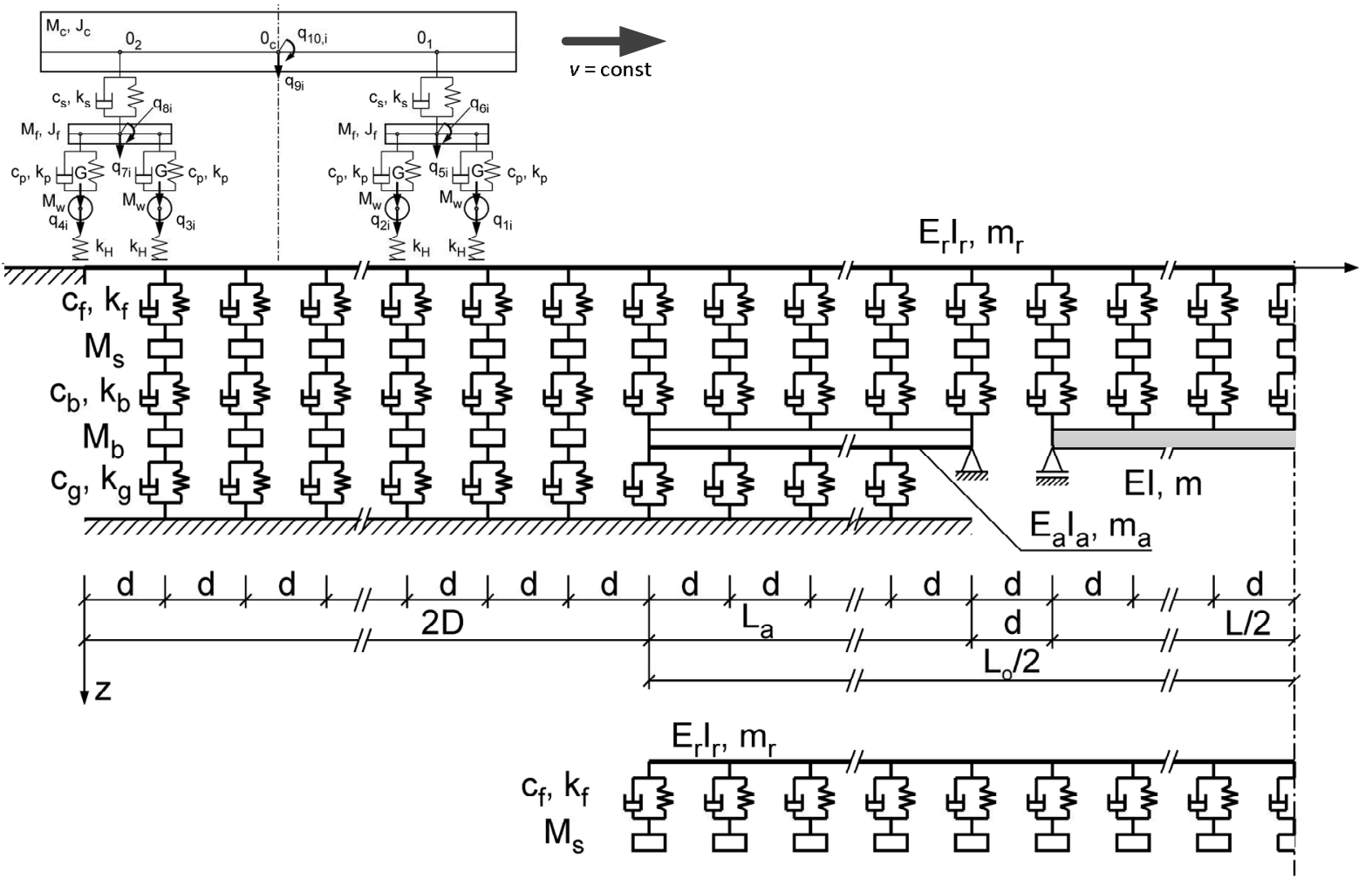

2. A flat physical model of the system BTT (contaminated scale) 
To receive balance equations, the BTT system was diveded into smaller subsustems (look at pic.2), in order to load them with proper interaction forces. Codes from english terms was adopted:

BS (Bridge Superstructure) - complex supporting construction of the bridge which is mapped by beam piecewise prismatic, freely supported, flexible deformable, symetrical to the breadth centre, with suppression of the vibration of the supporting construction described by Reyleigh model [3].

LAS, RAS (Left / Right Approach Slab) - left and right transition board which are modeled as viscoelastic Euler's beams, articulately supported on the right / left end.

LB and RB (Left / Right Ballast - bed) - left and right layer of the ballast, medelled by discreet non-linear bonds elastic-damping under every subsystem. Mass of the ballast is granulated beyond the bridge and transition boards. Set of the masses is weight down by interaction forces transmitted by ballast and subsoil.

SL (Sleepers) - underlay, mapped by focused masses vibratin verticaly, weight down by set of the interactions transmitted by connectors of the tracks with underlays and by ballast

OR (Operating Rails) - the main tracks - viscoelastic Euler's beams

SR (Side Rails) - side tracks - as OR

(railway vehicle) - the train which consists of 8 four-axle vehicles, modeled with help of expanded Matsuura model described above. It is adopted that the train is moving with the constant speed.

Listed beam subsystems, digitized using finite elements flexible deformable (4DOF) with length equal to breadth underlays, are weight down by proper subsets of vertical interaction forces, transmitted by spring bonds or viscoelastic, linear or physical non-linear.

Using Lagrange's equations and aggregation, matrix linear movement equations of specyfic subsystems with physical non-linear generallized weighting down vectors noted in nonpublic form are received. Interaction forces are transformed on the generallized weighting down vectors. That formulation leads to the movement equations of subsystems with constant factors what repeatedly shortens the time needed to make a numerical calculations compared to not providing for Hertz contact siffness model [18, 19].

Non-stationary vibrations of the BTT system are described by matrix movement equation where it is a number of the moving rail vehicles. Coupling of these equations is hidden in generallized weighting down vectors expressed by interaction forces.

Detailed description of mathematical and physical modeling systems was described in a piece of work of M. Podwórna, M. Klasztorny [22].

Received matrix movement equations of subsystems belong to the class of ordinary diffrential equations, linear, and with permanent factors:

$\mathbf{B} \ddot{\mathbf{q}}(t)+\mathbf{C} \dot{\mathbf{q}}(t)+\mathbf{K q}(t)=\mathbf{F}[\mathbf{R}(t), t]$

interia matrixes, suppresion and stiffness of the specyfic inert subsystem - generallized weighting down vector of that subsystem, generally dependent on interaction forces vector and time variable. In the initial moment the train has a constant vertical speed and is located on the left nondeformable, rectilinear part of a track. The BTT system is in the balance and was described in the way in which every subsystem agrees with zero initial conditions.

$\mathbf{q}(0)=\mathbf{0}, \dot{\mathbf{q}}(0)=\mathbf{0}$.

Also, from the equation (3) in the initial moment receives is obtained $\ddot{\mathbf{q}}(0)=\mathbf{0}$.

Secret matrix movement equations (3) are totally numerical with initial terms $(4,5)$ with help of Newmark's average acceleration with $\beta_{N}=1 / 4, \gamma_{N}=1 / 2$ parameters, developed to secret form shown in a piece of work [18]. Should be noted that in case of open equations this method is absolutely stable. [20]

In a piece of work attention was focused on the result size - dynamic factor of vertical deflection of a beam in the centre of the bridge breadth 
$\varphi_{w}(0.5 L)=\frac{\max _{t} w(0.5 L, t)}{\max _{t} w_{s}(0.5 L, t)}$,

where:

- weaveforms of dynamic deflection of the beam in the centre of the bridge breadth for the exploitation speed of the train $\mathrm{km} / \mathrm{h}$ for the tack TI4, TI5, inequalities of the track agrees to levels of the railway lines (established values of the A factor according to American Railway Standard [8]) - $\quad$ weaveforms quasi-static deflection of the beam in the centre of the bridge for exploitation speed of the train $\mathrm{km} / \mathrm{h}$ for the plain track (NTI)

\section{Numeric analysis}

In this piece of work was analised the values of the dynamic factors of deflection of the vertical beams of series, inside of the brodges span breadth for 5 objects. In table 1 results for series SCB for two kinds of inequalities of the track agrees to levels of the railways lines are compiled. In the picture 3 results are illustrated for series SCB-15 (yellow), SCB-18 (green), SCB-21 (blue), SCB-24 (orange), SCB-27 (purple), for (TI4) for accepted anticipated resonating speeds - look at [21]. In the picture 4 presented example of time course of dynamic deflection of the beam in the centre of the breadth for the shortest object form series for two speeds and for two inequalities of the track.

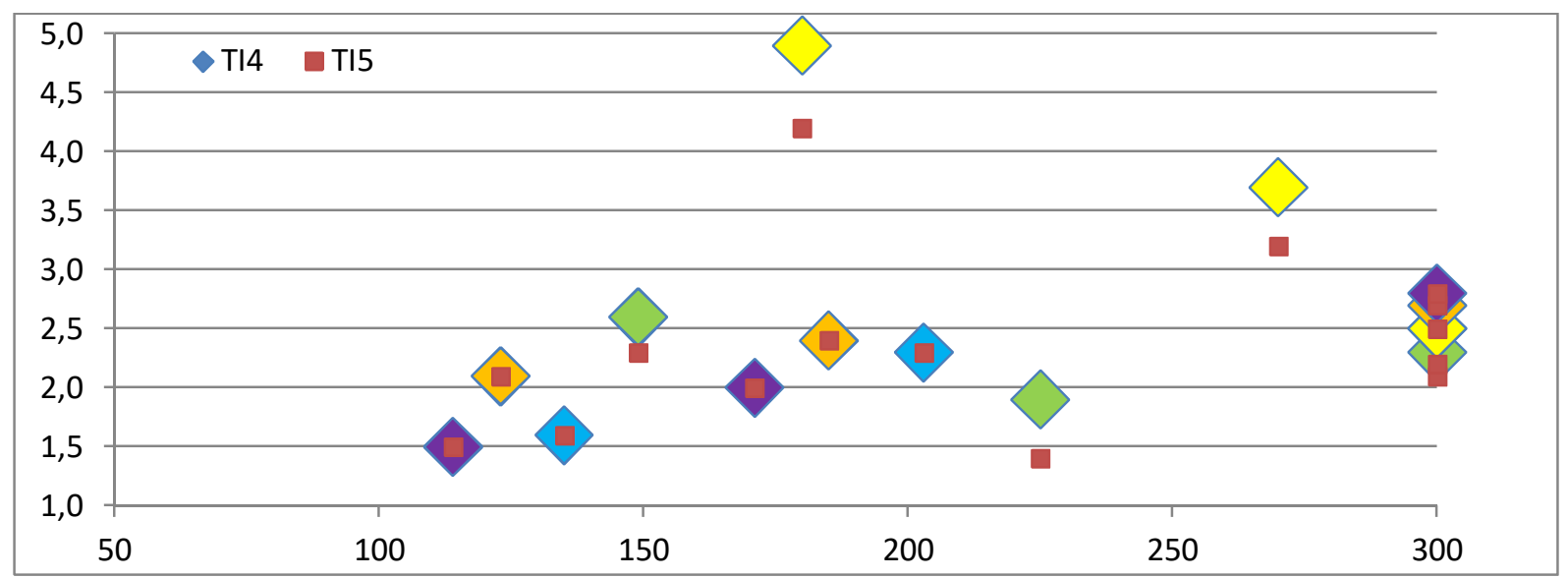

3. Diagram of deflection coefficients for the series of bridges depending on the speed 
Tab.1. Result sizes - dynamic deflection coefficients

\begin{tabular}{|c|c|c|c|}
\hline$v$ & {$[\mathrm{~km} / \mathrm{h}]$} & $\varphi_{w}(0.5 L)$ dla TI4 & $\varphi_{w}(0.5 L)$ dla TI5 \\
\hline \multicolumn{4}{|c|}{ SCB-15 } \\
\hline$v_{11}$ & 180 & $\mathbf{4 , 9}$ & 4,2 \\
\hline$v_{21}$ & 270 & 3,7 & 3,2 \\
\hline$v_{\max }$ & 300 & 2,5 & 2,2 \\
\hline \multicolumn{5}{|c|}{ SCB-18 } \\
\hline$v_{11}$ & 149 & 2,6 & 2,3 \\
\hline$v_{21}$ & 225 & 1,9 & $\mathbf{1 , 4}$ \\
\hline$v_{\max }$ & 300 & 2,3 & 2,1 \\
\hline \multicolumn{5}{|c|}{$\mathrm{SCB}-21$} \\
\hline$v_{11}$ & 135 & 1,6 & 1,6 \\
\hline$v_{21}$ & 203 & 2,3 & 2,3 \\
\hline$v_{\max }$ & 300 & 2,5 & 2,5 \\
\hline \multicolumn{5}{|c|}{$\mathrm{SCB}-24$} \\
\hline$v_{11}$ & 123 & 2,1 & 2,1 \\
\hline$v_{21}$ & 185 & 2,4 & 2,4 \\
\hline$v_{\max }$ & 300 & 2,7 & 2,7 \\
\hline \multicolumn{5}{|c|}{} & $\mathrm{SCB}-27$ & 1,5 \\
\hline$v_{11}$ & 114 & 1,5 & 2,0 \\
\hline$v_{21}$ & 171 & 2,0 & 2,8 \\
\hline$v_{\max }$ & 300 & 2,8 & \\
\hline
\end{tabular}

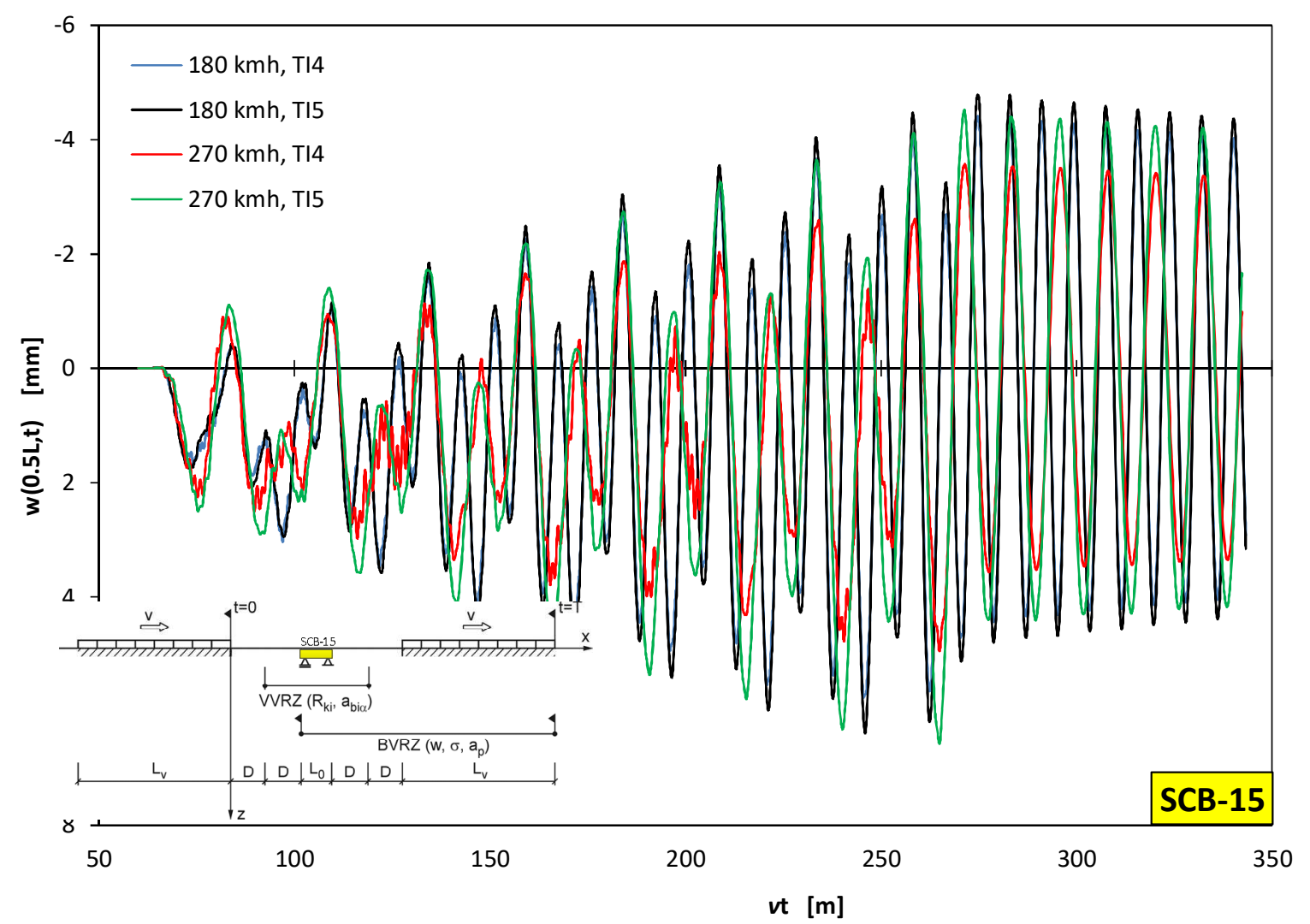

4. The time course of the dynamic deflection of the beam in the middle of the span of the bridge SCB-15 


\section{Colclusions}

Based on analisys above, the following main conclusions was made.

- $\quad$ For every three analized speeds, the biggest differences of the factors for inequalities of the track TI4, and track TI5, occur in the bridge with the theoritical breadth $15 \mathrm{~m}$.

- $\quad$ The biggest factor value was noticed in the shortest bridge SCB-15 with speed $=180 \mathrm{~km} / \mathrm{h}$ for the track with smaller equality (TI4).

- Comparing the track with inequality smaller (TI5) - the biggest factor value is also in the bridge SCB-15 with speed $=180 \mathrm{~km} / \mathrm{h}$

- The lowest factor value occurs in the bridge SCB-18 with speed $=225 \mathrm{~km} / \mathrm{h}$ for the track with bigger equality (TI5).

- $\quad$ In the larger bridges the bigger differences are unnoticeable in vertical factors of the middle part of the span deflection according to inequality of the track

- In the smallest bridge (SCB-15) is clear differencein factors of vertical deflection in the breadth centre of the bridge in according to the kind of inequality of the track

- $\quad$ Object with the smallest breadth (SCB-15) presents itself the least preferred against all the series with range of the theoretical breadth form $15 \mathrm{~m}$ to $27 \mathrm{~m}$ in analisys above and in researches with range of other criteria, for example comfort of passengers - look at [17].

\section{Source materials}

[1] Andersen L., Nielsen S., Vibrations of a track caused by variation of the foundation stiffness, Probabilistic Engineering Mechanics,2003. 18, 171-184.

[2] Au F.T.K., Wang J.J., Cheung Y.K., Impact study of cable stayed railway bridges with random rail irregularities, Engineering Structures,2002, 24, 529 - 541.

[3] Bachmann H., Vibration problems in structures. Practical guidelines, Basel - Boston - Berlin, Birkhuser, 1995.

[4] Bryja D., Hołubowski R.: Wpływ dużych prędkości w analizie stochastycznych drgań mostu kolejowego z losowo zmienną sztywnością podsypki. Journal of Civil Engineering, Environment and Architecture, 2014, 31, 61, 2, 15-32.

[5] Dahlberg T.: Railway track stiffness variations - consequences and counter-measures, International Journal of Civil Engineering, 2010, 8, 1, 1-12.

[6] EN 1990. Eurokod: Podstawy projektowania konstrukcji.

[7] EN 1991. Eurokod 1: Oddziaływania na konstrukcje. Część 2: Obciążenia ruchome mostów.

[8] Fryba L., A rough assessment of railway bridges for high speed trains, Engineering Structures, 2001, 23, $548-556$.

[9] http://www.hochgeschwindigkeitszuege.com/germany/index_ice_3.htm (2010)

[10] Karlikowski J., Madaj A., Wołowicki W., Mostowe konstrukcje zespolone stalowo-betonowe, WKiŁ, Warszawa, 2007.

[11] Lei X., Noda N.-A., Analyses of dynamic response of vehicle and track coupling system with random irregularity of track vertical profile, Journal Sound and Vibration, 2002, 258, 1, 147 165.

[12] Ning J., Lin J. Zhang B., Time-frequency processing of track irregularities in high-speed train, Mechanical Systems and Signal Processing, 2016, 66-67,339-348.

[13] PN-82/S-10052. Obiekty mostowe. Konstrukcje stalowe. Projektowanie.

[14] PN-85/S-10030. Obiekty mostowe. Obciążenia.

[15] PN-91/S-10042. Obiekty mostowe. Konstrukcje betonowe, żelbetowe i sprężone. Projektowanie.

[16] PN-EN15528 Kolejnictwo - Klasyfikacja linii.

[17] Podwórna M., Dynamic response of steel-concrete composite bridges loaded by high-speed train, Structural Engineering and Mechanics, 2017, 62, 2, 179-196. 
[18] Podwórna M., Dynamics of a bridge beam under a stream of moving elements. Part 1 - Modelling and numerical integration, Structural Engineering and Mechanics, 2011, 38, 3, 283-300.

[19] Podwórna M., Dynamics of a bridge beam under a stream of moving elements. Part 2 Numerical simulations, Structural Engineering and Mechanics, 2011, 38, 3 301-314.

[20] Podwórna M., Modelling of random vertical irregularities of railway tracks, International Journal of Applied Mechanics and Engineering, 2015, 20, 3, 663-671.

[21] Podwórna M., Klasztorny M., Vertical vibrations of composite bridge / track structure / highspeed train system. Part 1: Series-of-types of steel-concrete bridges, Bulletin of the Polish Academy of Science Technical Sciences, 2014, 62, 1, 165-179.

[22] Podwórna M., Klasztorny M., Vertical vibrations of composite bridge / track structure / highspeed train system. Part 2: Physical and mathematical modelling, Bulletin of the Polish Academy of Science Technical Sciences, 2014, 62, 1, 181-196.

[23] Rozporządzenie Ministra Infrastruktury i Rozwoju z dnia 5 czerwca 2014 r. zmieniające rozporządzenie w sprawie warunków technicznych, jakim powinny odpowiadać budowle kolejowe i ich usytuowanie.

[24] Rozporządzenie Ministra Transportu i Gospodarki Morskiej z dnia 10 września 1998 r. w sprawie warunków technicznych, jakim powinny odpowiadać budowle kolejowe i ich usytuowanie.

[25] Song M.-K., Noh H.-C., Choi C.-K., A new three dimensional finite element analysis model of high-speed train - bridge interactions, Engineering Structures, 2003, 25, 1611 - 1626.

[26] Towpik K., Specyfika projektowania, eksploatacji oraz utrzymania dróg -kolejowych dużych prędkości (KDP), Nowoczesne Budownictwo Inżynieryjne, 2013,88-91.

[27] Xu L., Zhai W. , Gao J., A probabilistic model for track random irregularities in vehicle/track coupled dynamics, Applied Mathematical Modelling, 2017, 51, 145-158.

[28] Zhang Y.-W., Lin J.-H., Zhao Y., Howson D.P., Williams F.W., Symplectic random vibration analysis of a vehicle moving on an infinitely long periodic track, Journal of Sound and Vibration, 2010, 329, 4440 - 4454.

[29] Zhi-wu Y., Jian-feng M., Feng-qi G., Wei G. Non-stationary random vibration analysis of a 3D train-bridge system using the probability density evolution method, 2016, Journal of Sound and Vibration, 366, 173-189. 